\title{
LEGIBILITY
}
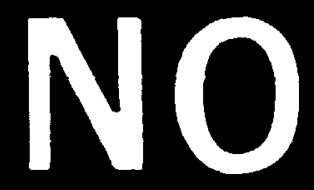

TIC

A major purpose of the Technical Information Center is to provide the broadest dissemination possible of information contained in DOE's Research and Development Reports to business, industry, the academic community, and federal, state and local governments.

Although a small portion of this report is not reproducible, it is being made available to expedite the availability of information on the research discussed herein. 


\title{
HEALTH ANC SAFETY RESEARCH DIVISION
}

Waste Management Research and Development Programs

(Activity No. AH 100500 0; NEAH001)

\section{RESULTS OF THE RADIOLOGICAL SURVEY AT 104 AVENUE E, LODI, NEW JERSEY (LJ086)}

\author{
R. D. Foley and L. M. Floyd
}

Date Published - December 1989

Investigation Team

R. E. Swaja - Measurement Applications and Development Manager W. D. Cottrell - FUSRAP Project Director

R. D. Foley - Field Survey Supervisor

\section{Survey Team Members}
A. C. Butler*
V. H. Shinpaught
R. A. Mathis
P. F. Tiner

W. Winton

*Former Employee of Martin Marietta Energy Systems, Inc.

fDon Stone Associates

Work performed by the MEASUREMENT APPLICATIONS AND DEVELOPMENT GROUP

\author{
Prepared by the \\ OAK RIDGE NATIONAL LABORATORY \\ Oak Ridge, Teaneace 37831-6285 \\ operated by \\ MARTIN MARIETTA ENERGY SYSTEMS, INC. \\ for the \\ U. S. DEPARTMENT OF ENERGY \\ under contract DE-ACOS-84OR21400
}




\section{CONTENTS}

LIST OF FIGURES . . . . . . . . . . . . . . . . . . . v LIST OF TABLES ........................ . . vii ACKNOWLEDGMENTS ..................... . ix ABSTRACT ..................... . . . xi

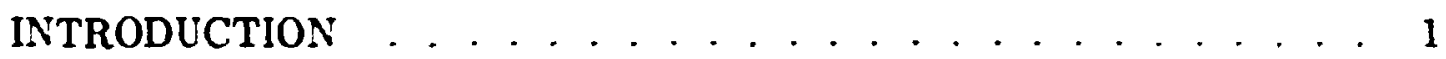
SURVEY METHODS . . . . . . . . . . . . . . . . . . . 2 SURVEY RESULTS . . . . . . . . . . . . . . . . . . . 2

Gamma Radiation Levels . . . . . . . . . . . . . . . . 2

Systematic Soil Samples . . . . . . . . . . . . . . . . 3 SIGNIFICANCE OF FINDINGS . . . . . . . . . . . . . . . . . . 3 REFERENCES ........................4 4 


\section{LIST OF FIGURES}

1 Gamma radiation levels $(\mu \mathrm{R} / \mathrm{h})$ measured on the surface at $104 \mathrm{Av}$ enue E, Lodi, New Jersev (LJ086), with corresponding measurements one meter above the surface where indicated

2 Diagram showing locations of soil samples taken at 104 A venue E, Lodi, New Jersey (LJ086) . . . . . . . . . . . . . . . 6 


\section{LIST OF TABLES}

1 Applicable guidelines for protection against radiation . . . . . . . . T

2 Backgrourd radiation levels for the rorthern New Jersey area . . . . i

3 Concentrations of radionuclides in soil at 104 Avenue E, Lodi, New Jersey (LJ086; . . . . . . . . . . . . . . . . . . . . 8 


\section{ACKNOWLEDGMENTS}

Research for this project was sponsored by the Division of Facility and Site Decommissioning Projects, U.S. Department of Energy, under contract DE-ACOS84OR21400 with Martin Marietta Energy Systems, Inc. The authors wish to acknowledge the support of J. E Baublitz, Acting Director, Office of kemedial Action and Waste Technolegy, J. J. Fiore, Direc:or, Division of Facility and Site Decommissioning Projects; and members of their staffs. The authors also appreciate the contributions of J. L Rich, S. W. Hawthorne, and L J. Jeffers of the Publications Division; M. S. Uziel of the Environmental Remediation Group; D. A Roberts and T. R. Stewart of the Measurement Applications and Development Group; A. C. Butler, former employee of Martin Marietta Energy Systems, Inc; and W. H. Shinpaugh of Don Stone Associates for participation in the collection, analyses, editing, and reporting of data for this survey. 


\begin{abstract}
Maywood Chemical Works (MCW) of Maywood, New Jersey, generated process wastes and residues ascociated with the production and refining of thorium and thorium compounds from monazite ores from 1916 to 1956 . MCW supplied rare earth metats and thorium compounds to the Atomic Energy Commixsion and various other government agencies from the late 1940 s to the mid-1950. Area residents used the sandlike waste from this thorium extraction process miced with tea and cocon leaves as mulch in their yards. Some of these contaminated wastes were also eroded from the site into Lodi Brook. At the request of the U.S. Department of Energy (DOE), a group from Oak Ridge National Laboratory conducts investigative radiological surveys of properties in the vicinity of $\mathrm{MCW}$ to determine whether 3 propert, is costamir.ated with radioactive residues, principally ${ }^{232} \mathrm{Th}$, derived from the MCW site. The survey typically includes direct measurement of gamma radiation levels and soil sampling for radionuclide analyes. The survey of this site, 104 Avenue E, Lodi, New Jersey (LJ086), was conducted during 1988.
\end{abstract}

Results of the survey demonstrated no radionuclide concentrations in excess of the DOE Formerly Utilized Sites Remedial Action Program criteria The radionuclide distributions were not significantly different from normal background levels in the northern New Jeriey area. 


\section{RESULTS OF THE RADIOLOGICAL SURVEY OF 104 AVENUE E, LODI, NEW JERSEY (LJ086)*}

\section{INTRODUCTION}

From 1916 to 1956, process wastes and residues associated with the production and refining of thorium and thorium compounds from monazite ores were generated by the Maywood Chemical Works (MCW), Maywood, New Jersey. During the latter part of this period, MCW supplied rare earth metals and thorium compounds to various government agencies. In the 1940 s and 1950s, MCW produced thorium and lithium, under contract, for the Atomic Energy Commission (AEC). These activities ceased in 1956, and, approcimately three years later, the 30-acre real estate was purchased by the Stepan Company. The property is located at 100 Hunter Avenue in a highly developed area in Maywood and Rochelle Park, Bergen County, New Jersey.

During the early years of operation, MCW stored wastes and residues in lowlying areas west of the processing facilities. In the early 1930s, these areas were separated from the rest of the property by the construction of New Jersey State Highway 17. The Stepan property, the interim storage facility, and several vicinity properties have been r.esignated for remedial action by the U.S. Department of Energy (DOE).

The waste produced by the thorium extraction process was a sandlike material containing residual amounts of thorium and its decay products, with smaller quantities of uranium and its decay products. During the years 1928 and 1944 to 1946, area residents used these process wastes mixed with tea and cocoa leaves as mulch in their lawns and gardens. In addition, some of the contaminated wastes were apparently eroded from the site into Lodi Brook and carried downstream.

Lodi Brook is a small stream flowing south from Maywood with its headwaters near the Stepan waste storage site. Approximately $150 \mathrm{ft}$ after passing under State Route 17, the stream has been diverted underground through concrete or steel culverts until it merges with the Saddle River in Lodi, New Jersey. Only a small section near Interstate 80 remains uncovered. From the 1940s to the 1970s when the stream was being diverted underground, its course was altered several times. Some of these changes resulted in the movement of contaminated soil to the surface of a few properties, where it is still in evidence. In other instances, the contaminated soil was covered over or mixed with clean fill, leaving no immediate evidence on the surface. Therefore, properties in question may be drilled in search of former streambed material, even in the absence of surface contamination.

As a result of the Energy and Water Appropriations Act of Fiscal Year 1984, the property discussed in this report and properties in its vicinity contaminated with residues from the former MCW were included as a decontamination research

\footnotetext{
*The survey was performed by members of the Meaurement Applications and Development Group of the Health and Safety Research Division at Oak Ridge National Laboratory under DOE contract DE-AC05-84OR21400.
} 
and development project under the DOE Formerly ¿tilized Sites Remedial Action Program. As part of this project, DOE is conducting radiological surveys in the vicinity of the site to identify properties contaminated with residues derived from the $\mathrm{MCW}$. The principal radionuclide of concern is thorium-232. The radiological surveys discussed in this report are part of that effort and were conducted, at the request of DOE, by members of the Measurement Applications and Development Group of the Oak Ridge National Laboratory.

A radiological survey of the private, residential property at 104 Avenue $E$, Lodi, New Jersey, was conducted during 1988. The survey and sampling of the ground surface were carried out on May 9, 1988.

\section{SURVEY METHODS}

The radiological survey of the property included: (1) a gamma scan of the entire property outdoors, both at the surface and one meter above the surface and (2) collection of soil samples. These survey methods followed the plan outlined in Reference 1. No indoor survey measurements were performed.

Using a portable gamma scintillation meter, ranges of measurements were recorded for areas of the property surface and one meter above the surface. Systematic soil samples were taken at various Jocations on the property, irrespective of gamma radiation levels. A comprehensive description of the survey methods and instrumentation has been presented in another report. ${ }^{2}$

\section{SURVEY RESULTS}

Applicable federal guidelines are summarized in Table $1 .^{3}$ The normal background radiation levels for the northern New Jersey area are prosented in $\mathrm{Ta}$ ble 2.4,5 These data are provided for comparison with survey results presented in this report. All direct measurement results presented in this report are gross readings; background radiation levels have not been subtracted. Similarly, background concentrations have not been subtracted from radionuclide concentrations measured in environmental eamples.

\section{Gamma Radiation Levels}

Gamma radiation levels measured during a gamma scan of the surface of the property are given in Fig. 1, with corresponding measurements one meter above the surface where indicated. Gamma exposure rates over the major wortion of the property ranged from 5 to $9 \mu R / h$. Both one-metei measurements were $7 \mu R / h$; the normal background level at one meter is $8 \mu \mathrm{R} / \mathrm{h}$ for the northern New Jersey area (Table 2). The highest surface gamma levels were found around the front steps and the porch foundation, ranging from 10 to $13 \mu \mathrm{R} / \mathrm{h}$. This slight elevation in gamma levels is typical of the naturally occurring radioactive substances present in bricks, concrete, granite, and other such materials used in paving and building construction. Otherwise, none of the measurements were elevated. 


\section{Systematic Soil Samples}

Systematic soil samples were taken from various locations on the property for radionuclide analyses. Locations of these samples (S) are shown in Fig. 2, with results of laboratory analyses provided in Table 3 . Concentrations of radium, thorium, and uranium in these samples ranged from 0.73 to $0.76 \mathrm{pCi} / \mathrm{g}$, 0.84 to $0.88 \mathrm{pCi} / \mathrm{g}$, and 0.92 to $<3.4 \mathrm{pCi} / \mathrm{g}$, respectively. All samples were below DOE criteria (Table 1) and were not significantly different from background levels for the northern New Jersey area (Table 2).

\section{SIGNIFICANCE OF FINDINGS}

Measurements and results of soil sample analyses taken at $104 \mathrm{Avenue} E$ indicate that the property contained no radionuclide concentrations above DOE gi ideline values. The radionuclide distributions on this property were similar to normal background levels for the northern New Jersey area. 


\section{REFERENCES}

1. W. D. Cottrell, ORNL, to A. J. Whitman, DOE/HQ, correspondence, "Radiological Survey of Private Properties in Lodi, New Jersey" (August 15, 1984).

2. T. E. Myrick, B. A. Berven, W. D. Cottrell, W. A. Goldsmith, and F. F. Haywood, Procedures Manual for the ORNL Radiological Survey Activities (RASA) Program, Oak Ridge National Laboratory, ORNL/TM-8600 (April 1987).

3. U.S. Department of Energy, Guidelines for Residual Radioactive Material at Formerly Utilized Sites Remedial Action Program and Remote Surplus Facilities Management Program Sites (Rev. 2, March 1987).

4. U.S. Department of Energy, Radiological Survey of the Middlesex Municipal Landfill, Middlesex, New Jersey, DOE/EV-00005/20 (April 1980).

5. T. E. Myrick, B. A. Berven, and F. F. Haywood, State Background Radiation Levels: Results of Measurements Taken During 1975-1979, Oak Ridge National Laboratory, ORNL/TM-7343 (November 1981). 
OPNL-DWG 89-10661

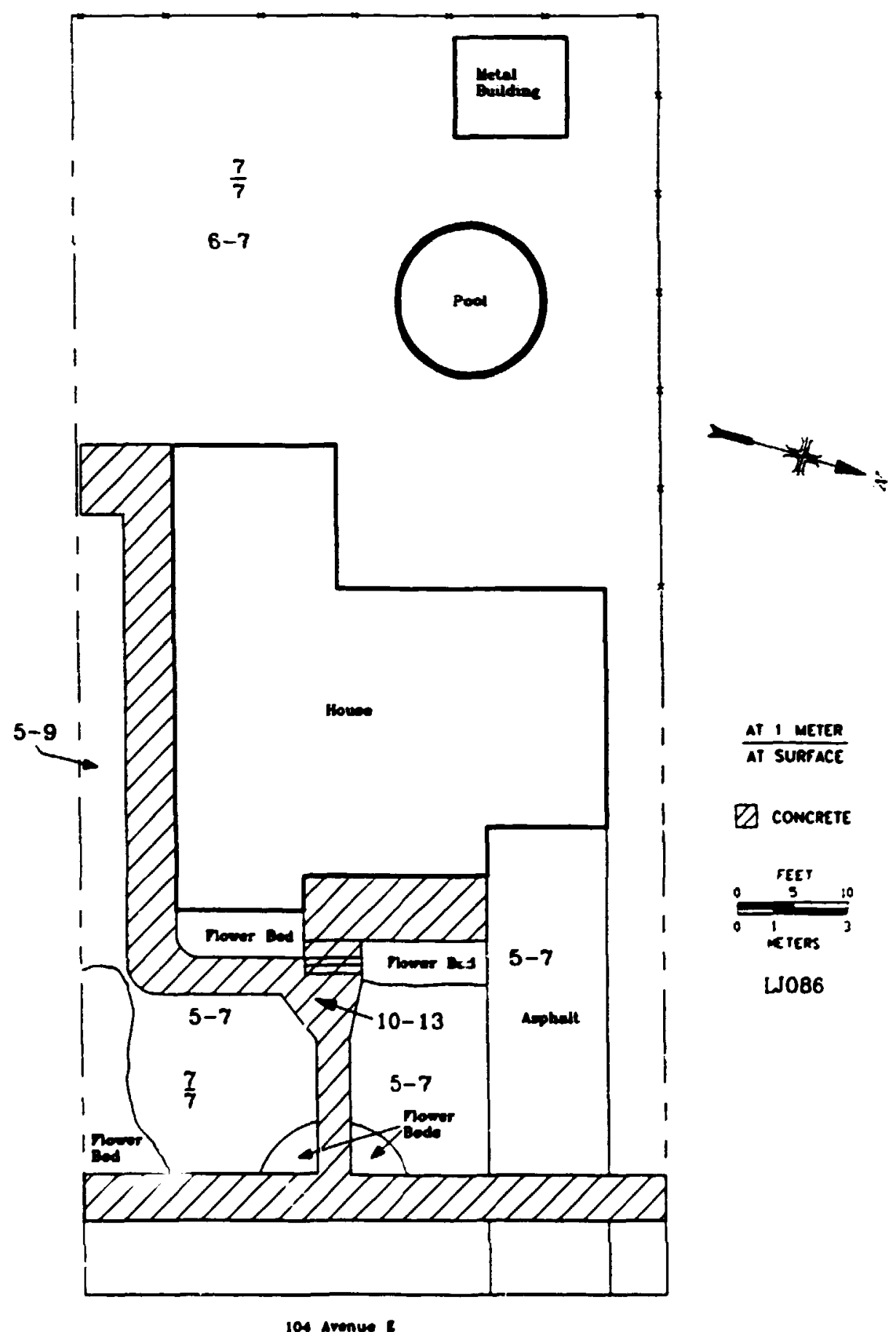

Fig. 1. Gamma radiation levels ( $\mu R / b)$ measured on the durface at 104 Avenue E, Lodi, New Jerscy (LJ086), with corresponding measurcments onc meler abuve the surface where indicated. 


\section{a)}

6

ORNL-DWG B9-10862
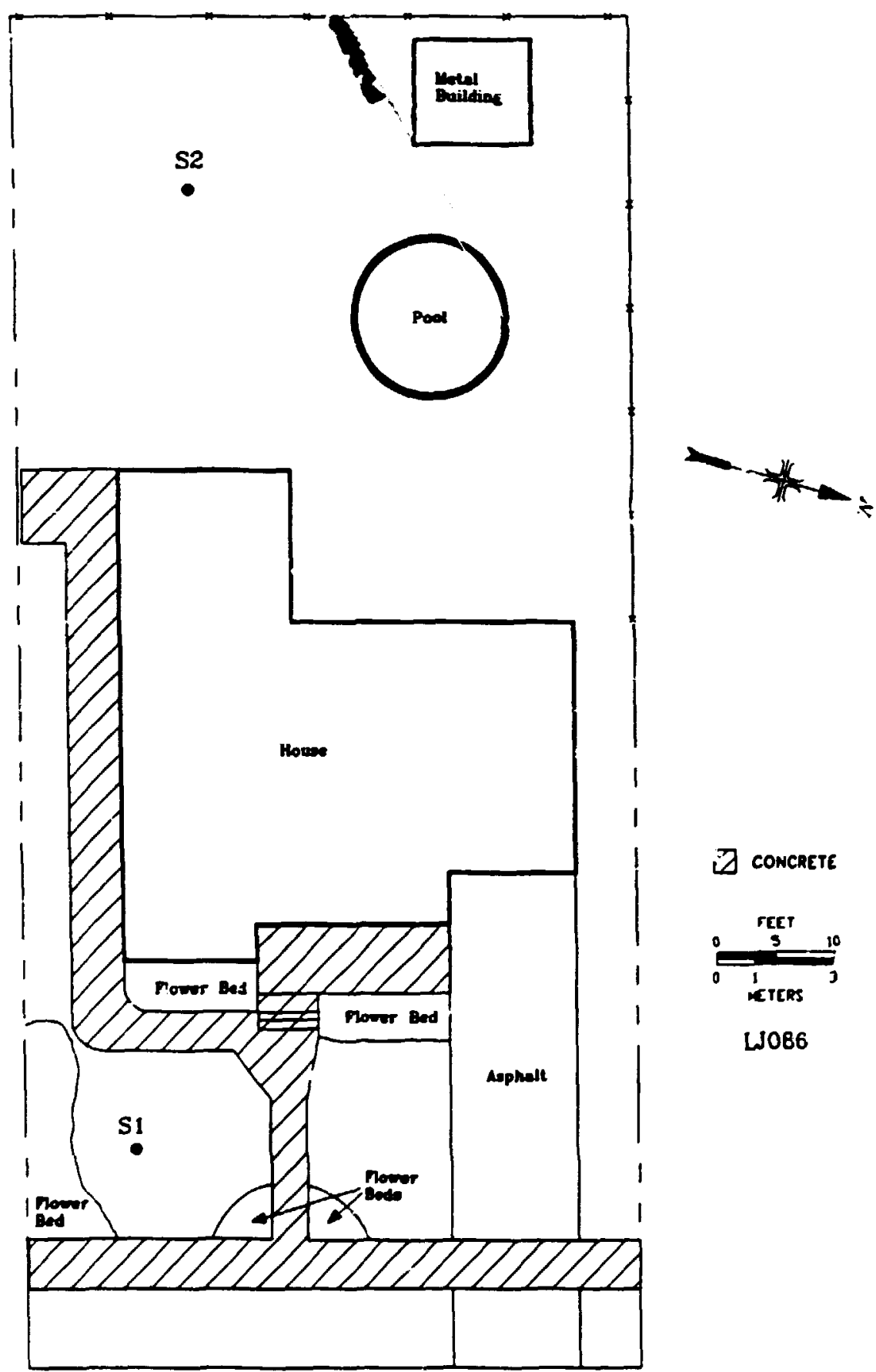

$\oslash$ CONCRETE

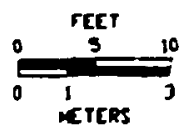

LNOB6

104 avenue $E$

Fig. 2 Diagram stowing locations of soil samples taken at 104 Avenuc E, Lodi, New Jerscy (LJ086). 
Table 1. Applicable guidelines for protection against radiation"

$\begin{array}{lll}\text { Mode of exposure } \quad \text { Exposure conditions } & \text { Guideline value }\end{array}$

\begin{tabular}{lll}
\hline $\begin{array}{l}\text { Radionuclide concen- } \\
\text { trations in soil }\end{array}$ & $\begin{array}{c}\text { Maximum permissible con- } \\
\text { centration of the follow- } \\
\text { ing radionuclides in soil } \\
\text { above background levels } \\
\text { averaged over } 100 \mathrm{~m}^{2} \text { area }\end{array}$ & $\begin{array}{l}5 \mathrm{pCi} / \mathrm{g} \text { averaged over the first } \\
15-\mathrm{cm} \text { of soil below the sur- } \\
\text { face; } 15 \mathrm{pCi} / \mathrm{g} \text { when averaged } \\
\text { over } 15-\mathrm{cm} \text { thick soil layers } \\
\text { more than } 15 \mathrm{~cm} \text { below the } \\
230 \mathrm{Th}\end{array}$ \\
$\begin{array}{l}228 \mathrm{Ra} \\
226 \mathrm{Ra}\end{array}$ \\
$238 \mathrm{U}$ & surface \\
& Derived (site specific) \\
\hline
\end{tabular}

'Reference 3.

Table 2. Background radiation levels for the northern New Jersey area

Type of radiation measurement

Radiation level or or sample radionuclide concentration ${ }^{\circ}$

\begin{tabular}{cc}
\hline $\begin{array}{c}\text { Gamma exposure at } 1 \mathrm{~m} \text { above } \\
\text { grou }-d \text { surface }(\mu \mathrm{R} / \mathrm{h})\end{array}$ & $\mathbf{8}^{\mathbf{b}}$ \\
& \\
Concentration of radionuclides & \\
in soil $(\mathrm{pCi} / \mathrm{g})$ & \\
$226 \mathrm{Ra}$ & 0.9 \\
$232 \mathrm{Th}$ & 0.9 \\
$238 \mathrm{U}$ & 0.9
\end{tabular}

These values represent an average of normal radionuclide concentrations in this part of the state. Actual values may nuctuate.

'Reference 4.

Reference 5. 
Table 3. Concentrations of radionuclides in soil at 104 Avenue E, Lodi, New Jersey (LJ086)

\begin{tabular}{|c|c|c|c|c|}
\hline \multirow{2}{*}{ Sample ${ }^{a}$} & \multirow{2}{*}{$\begin{array}{c}\text { Depth } \\
\text { (cm) }\end{array}$} & \multicolumn{3}{|c|}{ Radionuclide concentration $(\mathrm{pCi} / \mathrm{g}$ ) } \\
\hline & & ${ }^{226} \mathrm{Ra}^{6}$ & ${ }^{232} \mathrm{Ch}^{6}$ & ${ }^{238} \mathrm{U}^{6}$ \\
\hline \multicolumn{5}{|c|}{ Systematic samples ${ }^{c}$} \\
\hline $\begin{array}{l}\text { S1A } \\
\text { S1B }\end{array}$ & $\begin{array}{r}0-15 \\
15-30\end{array}$ & $\begin{array}{l}0.76 \pm 0.04 \\
0.74 \pm 0.02\end{array}$ & $\begin{array}{l}0.88 \pm 0.08 \\
0.88 \pm 0.04\end{array}$ & $\begin{array}{r}1.0 \\
<3.4\end{array}$ \\
\hline $\begin{array}{l}\text { S2A } \\
\text { S2B }\end{array}$ & $\begin{array}{r}0-15 \\
15-30\end{array}$ & $\begin{array}{l}0.73 \pm 0.008 \\
0.73 \pm 0.02\end{array}$ & $\begin{array}{l}0.34 \pm 0.01 \\
0.86 \pm 0.04\end{array}$ & $\begin{array}{l}0.92 \pm 0.3 \\
<1.4\end{array}$ \\
\hline
\end{tabular}

${ }^{a}$ Locations of soil samples are shown on Fig. 2.

${ }^{6}$ Indicated ccunting error is at the $95 \%$ confidence level $( \pm 2 \sigma)$.

'Systematic samples are taken at locations irrespective of gamma exposure rates. 